\title{
Response of Washington Navel Orange Trees to Some Soil Amendments and Foliar application of $\mathrm{GA}_{3}$ under Clay Soil Conditions
}

\author{
M. I. Salama*, R. A. Sayed ${ }^{* *}$, A. R. El-Shereif" and M. A. Mankolah ${ }^{* *}$ \\ ${ }^{*}$ Pomology Department, Faculty of Agriculture, Kafrelsheikh University and \\ ${ }^{* *}$ Citrus Department, Horticulture Research Institute, Agricultural Research \\ Center, Cairo, Egypt.
}

\begin{abstract}
T HIS STUDY was carried out during the two successive growing seasons of 2014 and 2015 on eight years old Washington navel orange trees budded on sour orange rootstock grown in a private orchard located at Shino village, Kafrelsheikh governorate, Egypt, to evaluate the effects of some soil amendments and $\mathrm{GA}_{3}$ foliar application on vegetative growth, nutritional status, yield and fruit quality as well as soil properties. The experiment was arranged in a randomized complete blocks design with eleven combination treatments as follows: $\left(\mathrm{T}_{1}\right)$ control or untreated trees, $\left(\mathrm{T}_{2}\right)$ mycorrhizae at $15 \mathrm{~g} /$ tree/year, $\left(\mathrm{T}_{3}\right)$ mycorrhizae at $15 \mathrm{~g} /$ tree $/$ year + sulphur at $1 \mathrm{~kg} /$ tree $/$ year, $\left(\mathrm{T}_{4}\right)$ mycorrhizae fungi at $15 \mathrm{~g} /$ tree/year + Nile fertile at $750 \mathrm{~g} /$ tree /year, $\left(\mathrm{T}_{5}\right)$ mycorrhizae at $15 \mathrm{~g} /$ tree/year + bio-tol at $2 \mathrm{~cm} / 1$ was sprayed from Feb. up to May, $\left(\mathrm{T}_{6}\right)$ mycorrhizae + sulphur $+30 \mathrm{ppm} \mathrm{GA}_{3}$ was sprayed at full bloom stage, $\left(\mathrm{T}_{7}\right)$ mycorrhizae + Nile fertile $+30 \mathrm{ppm} \mathrm{GA},\left(\mathrm{T}_{8}\right)$ mycorrhizae + bio-tol +30 ppm $\mathrm{GA}_{3},\left(\mathrm{~T}_{9}\right)$ phosphorine (bio-fertal) at $11 \mathrm{~g} /$ tree/year + Nile fertile, $\left(\mathrm{T}_{10}\right)$ Phosphorine + bio-tol $+30 \mathrm{ppm} \mathrm{GA}$ and $\left(\mathrm{T}_{11}\right)$ phosphorine + sulphur $+30 \mathrm{ppm} \mathrm{GA}$. The results indicated that trees treated with $\mathrm{T}_{11}$ had remarked effect followed by $\mathrm{T}_{7}$ than the other treatments in most of vegetative growth parameters (canopy volume, leaf area, leaf dry weight and specific leaf weight, at the spring growth cycle) and increased leaf chlorophyll and mineral contents in both seasons. $T_{11}$ followed by $\mathrm{T}_{10}, \mathrm{~T}_{9}, \mathrm{~T}_{8}$ and $\mathrm{T}_{7}$ achieved the best fruit yield and fruit quality compared with untreated trees. Soil $\mathrm{pH}$ and salinity (EC) were decreased while available macronutrients (N, P and K), soil microorganisms content and dehydrogenase activity were increased with applying $\mathrm{T}_{11}, \mathrm{~T}_{10}$, $\mathrm{T}_{9}, \mathrm{~T}_{8}, \mathrm{~T}_{7}, \mathrm{~T}_{6}$ and $\mathrm{T}_{5}$ comparing with control $\left(\mathrm{T}_{1}\right)$. Therefore, both $\mathrm{T}_{11}$ and $\mathrm{T}_{7}$ treatments are recommended for citrus orchard to improve growth, yield and quality as well as soil properties and comforting higher return for orange trees growers under Kafrelsheikh governorate conditions.
\end{abstract}

Keywords: Washington Navel orange, Soil amendments, Mycorrhizae, Sulphur, Nile fertile, .Bio-tol, $\mathrm{GA}_{3}$, Vegetative growth, Yield, Soil properties

\section{Introduction}

Citrus is one of the greatest important world fruit crops grown in many tropical and subtropical regons. In Egypt citrus trees occupies the greatest acreage among all fruit trees. The fruiting acreage of citrus occupies about 439024 fed and produced about 4098590 tons with average of 9.336 tons/ fed as stated by Ministry of Agriculture and Land Reclamation (2014). Bio-fertilization is considered an important tool to enhance the yield and fruit quality of citrus and it becomes a positive alternative to chemical fertilizers. They are safe for human, animal and environment and using them was attended with reducing the great pollution occurred on our environment as well as for producing organic foods for export. They are favorable in increasing $\mathrm{N}$ fixation (ElKhawaga, 2007). The availability and uptake of nutrients as well as stimulation of natural hormones biosynthesis and the production of antibiotics (Subba-Rao, 1993). So the use of microorganisms was favorable in increasing $\mathrm{N}$ fixation (Azospirillum lipoferum), solubilize phosphate (Bacillus megaterium) and potassium (Bacillus circulans), the availability and uptake of nutrients as well as stimulation of natural hormones biosynthesis and the production of antibiotics (Sherif, 1997). Arbuscular mycorrhizal 
(AM) fungi are universal soil organisms that can form mutualistic relations with the roots of the common of vascular plant species, also the establishment of AM association is often favorable for plant nutrition specially enhance absorption of phosphours and other relatively immobile micronutrients, particularly zinc and copper also AM fungi produce plant growth hormones such as auxines, cytokinines, gibberellins and increasing water uptake (Lindermann, 1988). Elemental sulphur, as a soil amendment, is of special interest to increase plant nutrient availability in the soil system since it possesses a slow release acidifying characteristic and is readily available (Chien et al., 2011). In the North Nile Delta region, major agricultural land is heavy clay soil relatively high $\mathrm{pH}$, resulting in high $\mathrm{pH}$ of the soils, which directly influence the availability of nutrients for plant growth. Elemental sulfur (S) can be used as a nutrient and an acidifier (Neilsen et al., 1993). The acidity produced during elemental $\mathrm{S}$ oxidation increases the availability of nutrients such as $\mathrm{P}$, $\mathrm{Mn}, \mathrm{Ca}$ and $\mathrm{SO}_{4}$ in soil (Lindemann et al., 1991). Various studies reported the importance of sulfur in increasing growth and leaf mineral content of some fruit trees, such as orange trees, grapevine and persimmon (Abdel-Nasser and El-Shazly,
2000). Plant growth regulators like as $\mathrm{GA}_{3}$ have been used in citrus production with numerous purposes like as bloom reduction, increased fruit setting and improving fruit quality. Therefore, the main objective of study is to evaluate the possible effects of some soil amendments and foliar application of $\mathrm{GA}_{3}$ on, growth, nutritional status, yield and quality of Washington Navel orange trees grown in clay soil along with soil properties.

\section{Materials and Methods}

The present investigation was carried out during the two successive growing seasons of 2014 and 2015 on eight years old Washington navel orange trees (Citrus sinensis L., Osbek) budded on sour orange (Citrus aurantium L.), planted at $5 \times 5$ meters apart (168 trees/fed.) and grown on clay soil in private orchard located at Shino village, Kafrelsheikh governorate, Egypt. The trees were irrigated with Nile water by flood irrigation system and received the same cultural practices as usually done in this area. Some chemical and physical properties of the experimental soil were determined according to Page et al. (1982) are presented in Table 1.

TABLE 1. Some physical chemical properties of the experimental soil

\begin{tabular}{|c|c|c|c|c|c|c|c|c|c|}
\hline \multirow[t]{2}{*}{$\begin{array}{c}\begin{array}{c}\text { Soil depth } \\
(\mathrm{cm})\end{array} \\
\end{array}$} & \multicolumn{3}{|c|}{ Particle size distribution (\%) } & \multirow{2}{*}{ pH } & \multirow[t]{2}{*}{$\begin{array}{c}\mathbf{E C}, \mathbf{d S} \\
\mathbf{m}^{-1} \\
\end{array}$} & \multirow[t]{2}{*}{$\begin{array}{c}\text { OM (g } \\
\left.\mathrm{kg}^{-1}\right)\end{array}$} & \multicolumn{3}{|c|}{$\begin{array}{c}\text { Available macronutrients } \\
\left(\mathrm{mg} \mathrm{kg}^{-1}\right)\end{array}$} \\
\hline & Sand & Silt & Clay & & & & $\mathbf{N}$ & $\mathbf{P}$ & $\mathbf{K}$ \\
\hline $0-30$ & 14.75 & 30.55 & 54.70 & 8.10 & 2.42 & 12.0 & 25.11 & 7.30 & 386.11 \\
\hline $30-60$ & 14.48 & 32.67 & 52.85 & 8.30 & 2.11 & 11.5 & 33.09 & 7.11 & 375.12 \\
\hline $60-90$ & 15.56 & 29.96 & 54.48 & 8.28 & 2.11 & 11.5 & 22.15 & 7.05 & 370.11 \\
\hline & & & & & & & & & \\
\hline
\end{tabular}

The experiment was arranged in a randomized complete blocks design with eleven combination treatments (each treatment was represented by three replicates, three trees /replicate) as follows:

$\mathrm{T}_{1}$-Control or untreated trees

$\mathrm{T}_{2}$-Mycorrhizae fungi at $15 \mathrm{~g} /$ tree /year.

$\mathrm{T}_{3}$-Mycorrhizae fungi at $15 \mathrm{~g} /$ tree $/$ year + Sulphur at $1 \mathrm{~kg} / \mathrm{tree} /$ year.

$\mathrm{T}_{4}$-Mycorrhizae fungi at $15 \mathrm{~g} /$ tree /year + Nile fertile at $750 \mathrm{~g} /$ tree $/$ year.

$\mathrm{T}_{5}$-Mycorrhizae fungi at $15 \mathrm{~g} /$ tree /year + Bio-tol at $2 \mathrm{~cm} / 1$ were sprayed from Feb. up to May.

$\mathrm{T}_{6}$-Mycorrhizae + Sulphur +30 ppm GA 3 sprayed at full bloom stage.

$\mathrm{T}_{7}-$ Mycorrhizae + Nile fertile $+30 \mathrm{ppm} \mathrm{GA}_{3}$.

$\mathrm{T}_{8}$-Mycorrhizae + Bio-tol +30 ppm GA .

$\mathrm{T}_{9}$-Phosphorine (Bio-fertal) at $11 \mathrm{~g} /$ tree / year + Nile fertile.

$\mathrm{T}_{10}$-Phosphorine (Bio-fertal) + Bio-tol $+30 \mathrm{ppm} \mathrm{GA}_{3}$.

$\mathrm{T}_{11}$-Phosphorine (Bio-fertal) + Sulphur +30 ppm GA.

The recommended doses of mineral fertilization N, P and K were 120, 30 and 80 units per fed., respectively were added. Sulphur and Nile fertile $30 \% \mathrm{~S}$ were added to the soil on the last week of January in two trenches with J. Sus. Agric. Sci. Vol. 43, No.1 (2017) depth of $10 \mathrm{~cm}$ and $100 \mathrm{~cm}$ apart from the tree trunk at both sides. Bio-fertilizers namely Biotol (Azospirillum ssp and Azotobacter ssp) for $\mathrm{N}$-fixing bacteria and Bacillus megaterium for phosphate-dissolving micro-organisms) and 
sprayed from Feb. up to May, Phosphorine (Biofertal) and Mycorrhizae (Glomus gigaspora) for $\mathrm{P}$, the counts of Mycorrhizae was $\left(1 \times 10^{8} \mathrm{cfu} /\right.$ $\mathrm{ml}$ (colony forming units). Nile fertile (NF) contains $30 \% \mathrm{~S}$, some essential elements, $(2.3 \%$ $\mathrm{N}, 5.5 \% \mathrm{P}, 0.5 \% \mathrm{~K}, 9 \% \mathrm{Ca}, 1.5 \% \mathrm{Mg}$ and $30 \%$ S) and sulphur bacteria, Thiobacillus ssp. $\left(10^{6}\right.$ CFU/g). Phosphorine (Bio-fertal), Mycorrhizae and Nile fertile were applied once during winter agricultural management by mixing with soil in wetting zone adhesive to the roots. During the growing season for each year, the following measurements and determinations were carried out.

\section{Vegetative growth parameters}

Number of shoots, shoot length, shoot diameter and number of leaves were calculated at the spring growth cycles. Tree canopy volume (CV) was measured according to (Castle, 1983) as follows: $\mathrm{CV}=0.528 \times \mathrm{H} \mathrm{X} \mathrm{D}^{2}$. Whereas, $\mathrm{H}=$ tree height, $\mathrm{D}=$ tree diameter. However, leaf area was estimated according to Chou (1966) via formula: Leaf area $=23$ / (length $\mathrm{x}$ width), leaf dry weight and specific leaf weight $\left(\mathrm{mg} / \mathrm{cm}^{2}\right)$ was calculated according to Ferre and Forshey (1988) as follows:

$$
\text { Specific leaf weight }(\text { SLW })=\frac{\text { Leaf dry weight }(\mathrm{mg})}{\text { Leaf area }\left(\mathrm{cm}^{2}\right)}
$$

\section{Nutritional status}

Chlorophyll a, b and its total were determined according to the method defined by Moran (1982), temporarily, leaf macro and micro nutrients contents were determined as follows: Total nitrogen was determined by micro-kjeldahl method described by Chapman and Pratt (1978). Phosphorus was determinedcoloremetricallyusingspectrophotometer $882 \mathrm{UV}$ at the wave length of $660 \mathrm{um}$ according to method described by Murphy and Riely (1962). Potassium was determined by Flame photometer according to method suggested by Jackson (1967).

\section{Yield and its components}

At harvest time $\left(20^{\text {th }}\right.$ and $25^{\text {th }}$ December in 2014 and 2015 seasons, respectively), yield as fruit number/tree, $\mathrm{kg} /$ tree, and ton/fed were calculated.

\section{Fruit quality}

To determine fruit quality, ten healthy fruits were taken at random from each tree at harvest time of both seasons and prepared for determination of physical and chemical fruit quality assessment according to (A.O.A.C., 1990).

\section{Soil properties}

At the end of experiment (20th December, 2015) soil samples for all treatments were collected at two depths $030-$ and $3060-\mathrm{cm}$ and data was expressed as average to measure some soil properties such as $\mathrm{pH}, \mathrm{EC}$, organic matter $\%$ and determine some chemical analysis, i.e. total nitrogen using Kjeldahl method, phosphorus and potassium (Page et al. 1982). Also, microorganisms were calculated as number of colonies/g soil according to Saleh (2002) and dehydrogenase activity ( $\mathrm{mg} \mathrm{g}^{-1}$ dry soil/ 96 h) was estimated according to Tabatabai (1982).

\section{Statistical analysis}

Data were statistically analyzed as analysis of varianceaccording toSnedecorandCochran(1990). Duncan's multiple range test (Duncan, 1955) at $5 \%$ level was used to compare the mean values.

\section{Results and Discussion}

\section{Vegetative growth}

Data presented in Table 2 show the effect of some soil amendments and foliar application of gibberellic acid on vegetative growth parameters in terms of canopy volume, number of shoot/branch, number of leaves/shoot, leaf area and specific leaf weight in 2014 and 2015 seasons. Trees treated with Phosphorine (Bio-fertal) + Sulphur $+30 \mathrm{ppm}$ $\mathrm{GA}_{3}\left(\mathrm{~T}_{11}\right)$ followed by $\mathrm{T}_{10}$ had remarked effect than the other treatments as for canopy volume in both seasons. Regarding to number of shoot/branch and number of leaves/shoot, data revealed that there were non-significant differences among treatments in both seasons. Looking for leaf area, $\mathrm{T}_{7}$ followed by $\mathrm{T}_{9}$ and $\mathrm{T}_{10}$ resulted the largest leaf area compared to the other treatments. However, treatments $\mathrm{T}_{7}, \mathrm{~T}_{8}$, $\mathrm{T}_{9}, \mathrm{~T}_{10}$ and $\mathrm{T}_{11}$ significantly increased specific leaf weight without significant differences among them compared to lowest value obtained by control $\left(\mathrm{T}_{1}\right)$ in both seasons. Generally, the above mentioned results indicated that, $\mathrm{T}_{11}$ and $\mathrm{T}_{10}$ followed by $\mathrm{T}_{9}, \mathrm{~T}_{8}$ and $\mathrm{T}_{7}$ were the best for improving the most of vegetative growth parameters of Washington Navel orange trees compared to other treatments and control (untreated trees). This may be attributed to the role of bio-fertilizers in increasing the level of available minerals from the organic matter (Ibrahim and Abd El-Aziz, 1977) and this improvement in vegetative growth of mycorrihizal inoculated trees could be attributed to produce a greater root having relatively higher total potential absorbing surface over than of the uninfected system which enhanced nutrient absorption particulary phosphorus and zinc (Nawar 
et al., 1988). In addition, Marks and Kozlowski (1973) reported that mycorrihiza fungi provide the host plant with growth hormones including auxins, cytokinins gibbrellines and vitamins which stimulate plant growth. The obtained increase in vegetative growth parameters as a result of sulphur application might be due to the role of $\mathrm{S}$ in reducing soil $\mathrm{pH}$ after oxidization by soil micro-organisms to sulphuric acid and improving the availability of most soil nutrients (Koriem, 1994). These results are in agreement with those obtained by Shamshiri et al (2012) on kinnow trees, El-Deeb et al (2013) on Valencia orange trees, Pawar et al. (2014) on acid lime trees, Soliman and Aaid (2016) on Le Conte pear and Zayan et al. (2016) on Washington navel orange trees. They found the application of all soil amendment treatments, biofertilizers and arbuscular mycorrhizae (AM) significantly increased vegetative growth parameters (trunk circumference, tree height, tree width and canopy volume) compared with control. However, Abd El Raheem et al. (2013) on navel orange trees noticed that, sparing trees with 4ppm CPPU +30 ppm GA 3 gave the largest leaf area when compared with untreated trees.

TABLE 2. Effect of some soil amendments and $\mathrm{GA}_{3}$ foliar application on vegetative growth parameters of Washington Navel orange trees in 2014 and 2015 seasons

\begin{tabular}{|c|c|c|c|c|c|c|}
\hline \multirow{2}{*}{ Treatments } & \multicolumn{2}{|c|}{ No. of leaves /shoot } & \multicolumn{2}{|c|}{$\begin{array}{l}\text { Leaf area } \\
\left(\mathrm{cm}^{2}\right)\end{array}$} & \multicolumn{2}{|c|}{ Specific leaf weight $\left(\mathrm{mg} / \mathrm{cm}^{2}\right)$} \\
\hline & 2014 & 2015 & 2014 & 2015 & 2014 & 2015 \\
\hline$T_{1}$ & $5.75 \mathrm{a}$ & $6.58 \mathrm{a}$ & $16.53 \mathrm{c}$ & $17.08 \mathrm{~d}$ & $0.011 \mathrm{c}$ & $0.011 \mathrm{~d}$ \\
\hline$T_{2}$ & $6.46 \mathrm{a}$ & $7.17 \mathrm{a}$ & $18.15 \mathrm{bc}$ & $18.41 \mathrm{~cd}$ & $0.012 \mathrm{bc}$ & $0.012 \mathrm{bcd}$ \\
\hline$T_{3}$ & $6.00 \mathrm{a}$ & $6.73 a$ & $19.04 \mathrm{ab}$ & $19.92 \mathrm{abc}$ & $0.013 \mathrm{abc}$ & $0.012 \mathrm{~cd}$ \\
\hline$T_{4}$ & $6.58 \mathrm{a}$ & $7.15 \mathrm{a}$ & $19.53 \mathrm{ab}$ & $20.68 \mathrm{ab}$ & $0.013 \mathrm{bc}$ & $0.011 \mathrm{~cd}$ \\
\hline$T_{5}$ & $6.67 \mathrm{a}$ & $7.27 \mathrm{a}$ & $17.95 \mathrm{bc}$ & $18.65 \mathrm{bcd}$ & $0.011 \mathrm{c}$ & $0.013 \mathrm{a}-\mathrm{d}$ \\
\hline$T_{6}$ & $6.62 \mathrm{a}$ & $7.25 \mathrm{a}$ & $17.93 \mathrm{bc}$ & $18.82 \mathrm{bcd}$ & $0.015 a b c$ & $0.014 \mathrm{a}-\mathrm{d}$ \\
\hline $\mathrm{T}_{7}$ & $6.68 \mathrm{a}$ & $7.43 a$ & $20.42 \mathrm{a}$ & $21.27 \mathrm{a}$ & $0.016 \mathrm{ab}$ & $0.017 \mathrm{a}$ \\
\hline $\mathrm{T}_{8}$ & $6.19 \mathrm{a}$ & $7.23 \mathrm{a}$ & $18.20 \mathrm{bc}$ & $18.92 \mathrm{bcd}$ & $0.017 \mathrm{a}$ & $0.015 \mathrm{ab}$ \\
\hline $\mathrm{T}_{9}$ & $6.34 \mathrm{a}$ & $6.87 \mathrm{a}$ & $18.12 \mathrm{bc}$ & $19.08 \mathrm{bcd}$ & $0.015 \mathrm{abc}$ & $0.015 a b c$ \\
\hline$T_{10}$ & $6.33 \mathrm{a}$ & $7.25 \mathrm{a}$ & $19.50 \mathrm{ab}$ & $20.72 a b$ & $0.017 \mathrm{a}$ & $0.016 \mathrm{ab}$ \\
\hline$T_{11}$ & $6.91 \mathrm{a}$ & $7.75 \mathrm{a}$ & $19.70 \mathrm{ab}$ & $20.78 a b$ & $0.017 \mathrm{a}$ & $0.017 \mathrm{a}$ \\
\hline
\end{tabular}

TABLE 2. Cont.

\begin{tabular}{|c|c|c|c|c|}
\hline \multirow{2}{*}{ Treatments } & \multicolumn{2}{|c|}{$\begin{array}{c}\text { Canopy volume } \\
\left(\mathbf{c m}^{3}\right)\end{array}$} & \multicolumn{2}{c|}{ No. of shoot / branch } \\
\cline { 2 - 5 } & $\mathbf{2 0 1 4}$ & $\mathbf{2 0 1 5}$ & $\mathbf{2 0 1 4}$ & $\mathbf{2 0 1 5}$ \\
\cline { 2 - 5 } & & $4.83 \mathrm{f}$ & $18.50 \mathrm{a}$ & $24.92 \mathrm{a}$ \\
\hline$T_{1}$ & $4.57 \mathrm{f}$ & $5.44 \mathrm{e}$ & $19.17 \mathrm{a}$ & $20.92 \mathrm{a}$ \\
\hline$T_{2}$ & $5.14 \mathrm{c}-\mathrm{f}$ & $5.52 \mathrm{de}$ & $22.33 \mathrm{a}$ & $24.08 \mathrm{a}$ \\
\hline$T_{3}$ & $5.35 \mathrm{cde}$ & $5.58 \mathrm{cde}$ & $21.33 \mathrm{a}$ & $20.83 \mathrm{a}$ \\
\hline$T_{4}$ & $5.24 \mathrm{cde}$ & $6.05 \mathrm{a}-\mathrm{d}$ & $17.67 \mathrm{a}$ & $23.00 \mathrm{a}$ \\
\hline$T_{3}$ & $5.57 \mathrm{bcd}$ & $5.55 \mathrm{de}$ & $24.08 \mathrm{a}$ & $25.83 \mathrm{a}$ \\
\hline$T_{6}$ & $5.06 \mathrm{def}$ & $5.93 \mathrm{~b}-\mathrm{e}$ & $25.75 \mathrm{a}$ & $27.40 \mathrm{a}$ \\
\hline$T_{5}$ & $5.39 \mathrm{cde}$ & $6.13 \mathrm{abc}$ & $19.17 \mathrm{a}$ & $21.65 \mathrm{a}$ \\
\hline$T_{8}$ & $5.77 \mathrm{abc}$ & $5.42 \mathrm{e}$ & $24.25 \mathrm{a}$ & $20.00 \mathrm{a}$ \\
\hline$T_{9}$ & $4.89 \mathrm{ef}$ & $6.57 \mathrm{a}$ & $22.42 \mathrm{a}$ & $23.83 \mathrm{a}$ \\
\hline$T_{10}$ & $6.22 \mathrm{a}$ & $6.40 \mathrm{ab}$ & $26.25 \mathrm{a}$ & $27.40 \mathrm{a}$ \\
\hline$T_{11}$ & $6.03 \mathrm{ab}$ & & & \\
\hline
\end{tabular}

Any values on the same vertical line for the same character having the same letter are not statistically different according to DMRT. $\mathrm{T}_{1}=$ Control (Untreated trees). $\quad \mathrm{T}_{2}=$ Mycorrhizae fungi at $15 \mathrm{~g} /$ tree/ year.

$\mathrm{T}_{3}=\mathrm{T}_{2}+$ Sulphur at $1 \mathrm{~kg} /$ tree/ year. $\mathrm{T}_{4}=\mathrm{T}_{2}+$ Nile fertile at $750 \mathrm{~g} /$ tree $/$ year.

$\mathrm{T}_{5}=\mathrm{T}_{2}+2 \mathrm{~cm} \mathrm{Bio-tol} / \mathrm{LL}$ water was sprayed at $\mathrm{Feb}$. up to May. $\quad \mathrm{T}_{6}=\mathrm{T}_{2}+$ Sulphur $+30 \mathrm{ppm} \mathrm{GA}$ was sprayed at full bloom stage.

$\mathrm{T}_{7}=\mathrm{T}_{2}+$ Nile fertile +30 ppm GA3. $\quad \mathrm{T}_{8}=\mathrm{T}_{2}+$ Bio-tol $+30 \mathrm{ppm} \mathrm{GA}_{3}$.

$\mathrm{T}_{9}=$ Phosphorine (Bio-fertal) at $11 \mathrm{~g} /$ tree/ year + Nile fertile. $\mathrm{T}_{10}=$ Phosphorine $($ Bio-fertal $)+$ Bio-tol $+30 \mathrm{ppm} \mathrm{GA}$.

$\mathrm{T}_{11}=$ Phosphorine (Bio-fertal) + Sulphur +30 ppm GA .

J. Sus. Agric. Sci. Vol. 43, No.1 (2017) 


\section{Nutritional status}

Leaf chlorophyll contents

Data in Table 3 declared that leaf chlorophyll contents ( $a, b$ and its total) were significantly influenced by the tested treatments in both seasons. The highest values of chlorophyll were recorded with $\mathrm{T}_{11}$ followed by $\mathrm{T}_{7}, \mathrm{~T}_{8}, \mathrm{~T}_{9}$ and $\mathrm{T}_{10}$ without significant differences among them comparing with the lowest values obtained by $\mathrm{T}_{1}$ (control) in both seasons. The increasing of leaf chlorophyll might be resulted from balanced concentration of $\mathrm{N}$ and Fe always lead to active synthesis of chlorophyll. This balance was clear in the obtained results on leaf mineral analysis in this study as shown in
Table 3. These results are similar to those obtained by Mikhael et al. (2009) on young persimmon trees, Shaban and Mohsen (2009) on Valencia orange, Abou-Zeed et al. (2014) on Balady mandarin trees, Merwed et al. (2014) on Valencia orange tree and Navarro et al. (2014) on Cleopatra mandarin trees.

\section{Leaf macronutrients contents}

Table 3 displayed that leaf N, P and K responded to treatments. Hence, fertilized Washington Navel orange trees with $\mathrm{T}_{7}, \mathrm{~T}_{10}$ and $\mathrm{T}_{11}$ had statistically the richest leaves in $\mathrm{N}$ without significant differences .among them in the second season only

TABLE 3. Effect of some soil amendments and $\mathrm{GA}_{3}$ foliar application on leaf macronutrients and chlorophyll contents of Washington Navel orange trees in 2014 and 2015 seasons

\begin{tabular}{|c|c|c|c|c|c|c|}
\hline \multirow{3}{*}{ Characters } & \multicolumn{6}{|c|}{$\begin{array}{l}\text { Leaf chlorophyll content } \\
\left(\mu \mathrm{g} / \mathrm{cm}^{2}\right)\end{array}$} \\
\hline & \multicolumn{2}{|c|}{ Chlorophyll a } & \multicolumn{2}{|c|}{ Chlorophyll b } & \multicolumn{2}{|c|}{ Total chlorophyll } \\
\hline & 2014 & 2015 & 2014 & 2015 & 2014 & 2015 \\
\hline $\mathrm{T}_{1}$ & $28.21 \mathrm{~d}$ & $26.82 \mathrm{c}$ & $13.47 \mathrm{~d}$ & $13.00 \mathrm{~d}$ & $41.68 \mathrm{e}$ & $39.82 \mathrm{c}$ \\
\hline $\mathrm{T}_{2}$ & $33.03 \mathrm{bc}$ & $35.73 \mathrm{ab}$ & $16.27 \mathrm{abc}$ & $15.82 \mathrm{c}$ & $49.30 \mathrm{bcd}$ & $51.55 \mathrm{~b}$ \\
\hline $\mathrm{T}_{3}$ & $32.50 \mathrm{c}$ & $35.77 \mathrm{ab}$ & $16.10 \mathrm{bc}$ & $16.57 \mathrm{c}$ & $48.60 \mathrm{~cd}$ & $52.33 \mathrm{~b}$ \\
\hline $\mathrm{T}_{4}$ & $35.71 \mathrm{abc}$ & $36.30 \mathrm{ab}$ & $17.48 \mathrm{ab}$ & $17.07 \mathrm{abc}$ & $53.20 \mathrm{abc}$ & $51.30 \mathrm{~b}$ \\
\hline $\mathrm{T}_{5}$ & $32.84 \mathrm{bc}$ & $34.20 \mathrm{~b}$ & $15.47 \mathrm{c}$ & $16.73 \mathrm{bc}$ & $48.31 \mathrm{~d}$ & $50.93 \mathrm{~b}$ \\
\hline $\mathrm{T}_{6}$ & $34.90 \mathrm{abc}$ & $34.03 \mathrm{~b}$ & $16.87 \mathrm{abc}$ & $17.27 \mathrm{abc}$ & $51.77 \mathrm{a}-\mathrm{d}$ & $52.27 \mathrm{~b}$ \\
\hline $\mathrm{T}_{7}$ & $36.47 \mathrm{ab}$ & $35.20 \mathrm{ab}$ & $17.07 \mathrm{ab}$ & $18.20 \mathrm{ab}$ & $53.06 \mathrm{abc}$ & $54.50 \mathrm{ab}$ \\
\hline $\mathrm{T}_{8}$ & $35.99 \mathrm{abc}$ & $36.63 \mathrm{ab}$ & $17.20 \mathrm{ab}$ & $17.07 \mathrm{abc}$ & $53.67 \mathrm{ab}$ & $53.70 \mathrm{ab}$ \\
\hline $\mathrm{T}_{9}$ & $36.35 \mathrm{ab}$ & $36.85 \mathrm{ab}$ & $17.33 \mathrm{ab}$ & $17.42 \mathrm{abc}$ & $53.68 \mathrm{ab}$ & $54.27 \mathrm{ab}$ \\
\hline $\mathrm{T}_{10}$ & $36.47 \mathrm{ab}$ & $36.67 \mathrm{ab}$ & $17.37 \mathrm{ab}$ & $17.30 \mathrm{abc}$ & $53.83 \mathrm{ab}$ & $53.97 \mathrm{ab}$ \\
\hline $\mathrm{T}_{11}$ & $36.85 \mathrm{a}$ & $37.73 \mathrm{a}$ & $17.75 \mathrm{a}$ & $18.57 \mathrm{a}$ & $54.60 \mathrm{a}$ & $56.30 \mathrm{a}$ \\
\hline
\end{tabular}

TABLE 3. Cont.

\begin{tabular}{|c|c|c|c|c|c|c|}
\hline \multirow{3}{*}{ Characters } & \multicolumn{6}{|c|}{ leaf macronutrients (\%) } \\
\hline & \multicolumn{2}{|c|}{$\mathbf{N}$} & \multicolumn{2}{|c|}{$\mathbf{P}$} & \multicolumn{2}{|c|}{$\mathbf{K}$} \\
\hline & 2014 & 2015 & 2014 & 2015 & 2014 & 2015 \\
\hline $\mathrm{T}_{1}$ & $2.10 \mathrm{a}$ & $2.20 \mathrm{e}$ & $0.20 \mathrm{e}$ & $0.21 \mathrm{~d}$ & $1.40 \mathrm{e}$ & $1.57 \mathrm{a}$ \\
\hline $\mathrm{T}_{2}$ & $2.47 \mathrm{a}$ & $2.63 \mathrm{abc}$ & $0.28 \mathrm{~cd}$ & $0.33 \mathrm{bc}$ & $1.48 \mathrm{de}$ & $1.67 \mathrm{a}$ \\
\hline $\mathrm{T}_{3}$ & $2.37 \mathrm{a}$ & $2.50 \mathrm{a}-\mathrm{e}$ & $0.23 \mathrm{e}$ & $0.32 \mathrm{bc}$ & $1.33 \mathrm{e}$ & $1.42 \mathrm{a}$ \\
\hline $\mathrm{T}_{4}$ & $2.30 \mathrm{a}$ & $2.30 \mathrm{cde}$ & $0.29 \mathrm{c}$ & $0.37 \mathrm{abc}$ & $1.62 \mathrm{~b}-\mathrm{e}$ & $1.83 \mathrm{a}$ \\
\hline $\mathrm{T}_{5}$ & $2.70 \mathrm{a}$ & $2.60 \mathrm{a}-\mathrm{d}$ & $0.30 \mathrm{bc}$ & $0.25 \mathrm{~d}$ & $1.53 \mathrm{de}$ & $1.66 \mathrm{a}$ \\
\hline $\mathrm{T}_{6}$ & $2.43 a$ & $2.70 \mathrm{ab}$ & $0.28 \mathrm{~cd}$ & $0.32 \mathrm{c}$ & $1.47 \mathrm{de}$ & $1.95 \mathrm{a}$ \\
\hline $\mathrm{T}_{7}$ & $2.50 \mathrm{a}$ & $2.73 \mathrm{a}$ & $0.24 \mathrm{de}$ & $0.38 \mathrm{ab}$ & $1.73 \mathrm{a}-\mathrm{d}$ & $1.62 \mathrm{a}$ \\
\hline $\mathrm{T}_{8}$ & $2.17 \mathrm{a}$ & $2.27 \mathrm{de}$ & $0.21 \mathrm{e}$ & $0.38 \mathrm{ab}$ & $1.58 \mathrm{cde}$ & $1.90 \mathrm{a}$ \\
\hline $\mathrm{T}_{9}$ & $2.27 \mathrm{a}$ & $2.37 \mathrm{~b}-\mathrm{e}$ & $0.30 \mathrm{bc}$ & $0.37 \mathrm{abc}$ & $1.88 \mathrm{ab}$ & $1.85 \mathrm{a}$ \\
\hline $\mathrm{T}_{10}$ & $2.77 \mathrm{a}$ & $2.80 \mathrm{a}$ & $0.34 \mathrm{ab}$ & $0.40 \mathrm{a}$ & $1.82 \mathrm{abc}$ & $1.96 \mathrm{a}$ \\
\hline $\mathrm{T}_{1}$ & $2.37 \mathrm{a}$ & $2.83 \mathrm{a}$ & $0.37 \mathrm{a}$ & $0.40 \mathrm{a}$ & $2.00 \mathrm{a}$ & $2.03 \mathrm{a}$ \\
\hline
\end{tabular}

Any values on the same vertical line for the same character having the same letter are not statistically different according to DMRT.

$\mathrm{T}_{1}=$ Control (Untreated trees). $\mathrm{T}_{2}=$ Mycorrhizae fungi at $15 \mathrm{~g} /$ tree/ year.

$\mathrm{T}_{3}=\mathrm{T}_{2}+$ Sulphur at $1 \mathrm{~kg} /$ tree$/$ year. $\mathrm{T}_{4}=\mathrm{T}_{2}+$ Nile fertile at $750 \mathrm{~g} /$ tree/year.

$\mathrm{T}_{5}=\mathrm{T}_{2}+2 \mathrm{~cm}$ Bio-tol $/ \mathrm{L}$ water was sprayed at Feb. up to May. $\mathrm{T}_{6}=\mathrm{T}_{2}+$ Sulphur $+30 \mathrm{ppm} \mathrm{GA}$ was sprayed at full bloom stage.

$\mathrm{T}_{7}=\mathrm{T}_{2}+$ Nile fertile $+30 \mathrm{ppm} \mathrm{GA} 3 . \quad \mathrm{T}_{8}=\mathrm{T}_{2}+$ Bio-tol $+30 \mathrm{ppm} \mathrm{GA}$.

$\mathrm{T}_{9}=$ Phosphorine $($ Bio-fertal $)$ at $11 \mathrm{~g} /$ tree $/$ year + Nile fertile. $\mathrm{T}_{10}=$ Phosphorine $($ Bio-fertal $)+$ Bio-tol +30 ppm GA .

$\mathrm{T}_{11}=$ Phosphorine (Bio-fertal) + Sulphur $+30 \mathrm{ppm} \mathrm{GA}_{3}$. 
tree, data revealed that number of fruits /tree was significantly increased under $\mathrm{T}_{11}$ and $\mathrm{T}_{10}$ treatments without significant differences between them compared to the lowest fruit number/ tree obtained with control $\left(\mathrm{T}_{1}\right)$ in the first season only, while in the second one the differences were non-significant. As for yield $(\mathrm{kg} /$ tree $)$, the results showed that there were statistically different within all treatments. Trees treated with $\mathrm{T}_{11}$ recorded the highest fruit yield /tree compared with the lowest yield recorded with control $\left(\mathrm{T}_{1}\right)$ in both seasons. The maximum yield (ton/fed.) was produced with trees treated by $\mathrm{T}_{10}$ and $\mathrm{T}_{11}$ without significant differences between them in the first season. Meanwhile, $\mathrm{T}_{11}$ gave the highest yield in the second one followed by $\mathrm{T}_{10}$ which gave the second rank. Increasing yield by using soil amendments and $\mathrm{GA}_{3}$ could be attributed to improve vegetative growth and nutritional status of the treated trees. This conclusion finds support in data presented in Tables 2 and 3. These results are in agreement with those reported by El-Deeb et al. (2013), EL-khawaga and Makled, (2013), Merwed et al. (2014) on Valencia orange trees and Zayan et al.. (2016) on Washington Navel orange trees. They found that treated trees with bio-fertilizer and Mycorrhizal fungi (VAM) achieved the best fruit yield. Wherease, Ashour et al.. (2009) on Balady orange trees and Murovhi (2013) on Valencia oranges trees. They found that application of sulphur or Nile fertile increased fruit yield as fruit weight and number of citrus fruits tree comparing with untreated trees. Also, Koller et al. (2000), Schafer et al.. (2000), Mohamed (2005) on Navel orange trees, Shinde et al.. (2008) and Manju and Rawat (2015) on local malta orange. They reported that spraying citrus trees with $\mathrm{GA}_{3}$ at full bloom increased the number of fruits and fruit yield when compared with untreated trees.

\section{Yield and its components}

Data presented in Table 4 disclose that $T_{11}$ increased fruit weight followed by $\mathrm{T}_{10}, \mathrm{~T}_{9} . \mathrm{T}_{8}$ and $\mathrm{T}_{7}$ without significant differences among them compared to $T_{1}$ and $T_{2}$ which recorded the lowest values in this respect in the first season only, while in the second one the differences were not significant. Concerning number of fruit /tree, data revealed that number of fruits /tree was significantly increased under $T_{11}$ and $\mathrm{T}_{10}$ treatments without significant differences between them compared to the lowest fruit number/ tree obtained with control $\left(\mathrm{T}_{1}\right)$ in the first season only, while in the second one the differences were non-significant. As for yield ( $\mathrm{kg} /$ tree), the results showed that there were statistically different within all treatments. Trees treated with $\mathrm{T}_{11}$ recorded the highest fruit yield /tree compared with the lowest yield recorded with control $\left(\mathrm{T}_{1}\right)$ in both seasons. The maximum yield (ton/fed.) was produced with trees treated by $\mathrm{T}_{10}$ and $\mathrm{T}_{11}$ without significant differences between them in the first season. Meanwhile, $\mathrm{T}_{11}$ gave the highest yield in the second one followed by $\mathrm{T}_{10}$ which gave the second rank. Increasing yield by using soil amendments and $\mathrm{GA}_{3}$ could be attributed to improve vegetative growth and nutritional status of the treated trees. This conclusion finds support in data presented in Tables 2 and 3. These results are in agreement with those reported by El-Deeb et al. (2013), EL-khawaga and Makled, (2013), Merwed et al. (2014) on Valencia orange trees and Zayan et al. (2016) on Washington Navel orange trees. They found that treated trees with bio-fertilizer and Mycorrhizal fungi (VAM) achieved the best fruit yield. Wherease, Ashour et al. (2009) on Balady orange trees and Murovhi (2013) on Valencia oranges trees. They found that application of sulphur or Nile fertile increased fruit yield as fruit weight and number of citrus fruits tree comparing with untreated trees. Also, Koller et al. (2000), Schafer et al. (2000), Mohamed (2005) on Navel orange trees, Shinde et al. (2008) and Manju and Rawat (2015) on local malta orange. They reported that spraying citrus trees with $\mathrm{GA}_{3}$ at full bloom increased the number of fruits and fruit yield when compared with untreated trees. 
Regarding to $\mathrm{P}$ content, data in the same table showed that there were significant differences among treatments in both seasons. Trees treated with $T_{10}$ and $T_{11}$ increased $P$ in leaves without significant differences between them in the first season, while in the second one $T_{10}$ and $T_{11}$ followed by $T_{7}$ and $T_{8}$ recorded the highest values comparing with control $\left(\mathrm{T}_{1}\right)$. Moreover, treated trees with $\mathrm{T}_{11}$ followed by $T_{10}$ and $T_{9}$ significant increased $\mathrm{K}$ in leaves comparing to control $\left(T_{1}\right)$ in the first season but in the second one the differences were not significant. This may be attributed to increase of nutrients availability as a result to reduction in soil $\mathrm{pH}$ Table 7 .

Moreover, Singh and Kappor (1999) point out that, plant hormones being released by mycorrhiza which increase plant root growth cause in turn increasing plant root surface which improves nutrients absorption. However, the observed benefits sulphur application might be attributed to increase of nutrients availability as a result of decreasing in soil $\mathrm{pH}$. A similar observation has been reported by, El-Deeb et al. (2013), on Valencia orange trees and El-Zawily (2016) on Washington Navel orange trees. They showed that the highest leaf $\mathrm{N}, \mathrm{P}$ and $\mathrm{K}$ resulted with orange tree inoculated with Mycorrhizal fungi or bio-fertilizer compared with untreated trees. In addition, Ashour et al. (2009) on Balady orange trees, Rizk-Alla and Tolba (2010) on Black Monukka grapevines, Murovhi (2013) on Valencia oranges and Soliman and Aaid (2016) on Le Conte pear trees. They found that all soil amendment treatments (Nile fertile at + AM fungi + biofertilizers) significantly increased leaf mineral contents $(\mathrm{N}, \mathrm{P}$ and $\mathrm{K}$ ) compared with control. While, Ismail (2007) on Tanarif sweet orange and Abo El-Enin (2012) on Navel orange trees, they reported that spraying trees with 25 ppm $\mathrm{GA}_{3}$ at full bloom increased leaf $\mathrm{N}, \mathrm{P}$ and $\mathrm{K}$ content.

TABLE 4. Effect of some soil amendments and $\mathrm{GA}_{3}$ foliar application on yield and its components of Washington Navel orange trees in 2014 and 2015 seasons

\begin{tabular}{|c|c|c|c|c|}
\hline \multirow{2}{*}{$\begin{array}{l}\text { Characters } \\
\text { Treatments } \\
\end{array}$} & \multicolumn{2}{|c|}{ Fruit weight (g) } & \multicolumn{2}{|c|}{ No. of fruit / tree } \\
\hline & 2014 & 2015 & 2014 & 2015 \\
\hline$T_{1}$ & $214.07 c$ & $332.33 \mathrm{a}$ & $305.00 \mathrm{i}$ & $188.33 a$ \\
\hline $\mathrm{T}_{2}$ & $218.40 \mathrm{c}$ & $403.13 \mathrm{a}$ & $310.00 \mathrm{~h}$ & $194.00 \mathrm{a}$ \\
\hline $\mathrm{T}_{3}$ & $223.07 \mathrm{bc}$ & $350.25 \mathrm{a}$ & $312.10 \mathrm{gh}$ & $183.33 \mathrm{a}$ \\
\hline$T_{4}$ & $222.87 b c$ & $327.57 \mathrm{a}$ & $315.07 \mathrm{fg}$ & $190.00 \mathrm{a}$ \\
\hline$T_{5}$ & $225.90 a b c$ & $371.20 \mathrm{a}$ & $318.23 \mathrm{ef}$ & $205.00 \mathrm{a}$ \\
\hline$T_{0}$ & $225.73 a b c$ & $390.77 \mathrm{a}$ & $320.23 \mathrm{e}$ & $187.33 \mathrm{a}$ \\
\hline $\mathrm{T}_{4}$ & $238.47 \mathrm{ab}$ & $344.53 \mathrm{a}$ & $325.23 \mathrm{~d}$ & $191.67 \mathrm{a}$ \\
\hline $\mathrm{T}_{8}$ & $231.67 a b c$ & $370.00 \mathrm{a}$ & $330.23 \mathrm{c}$ & $193.33 \mathrm{a}$ \\
\hline$T_{9}$ & $239.87 \mathrm{ab}$ & $361.27 \mathrm{a}$ & $335.07 \mathrm{~b}$ & $187.33 a$ \\
\hline$T_{10}$ & $241.55 \mathrm{ab}$ & $379.73 \mathrm{a}$ & $338.17 \mathrm{ab}$ & $199.33 \mathrm{a}$ \\
\hline$T_{11}$ & $243.60 \mathrm{a}$ & $358.00 \mathrm{a}$ & $340.07 \mathrm{a}$ & $205.00 \mathrm{a}$ \\
\hline
\end{tabular}


TABLE 4. Cont.

\begin{tabular}{|c|c|c|c|c|}
\hline Characters & & & $\begin{array}{r}\mathbf{Y} \\
\text { (To }\end{array}$ & \\
\hline 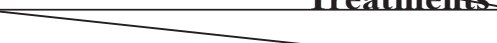 & 2014 & 2015 & 2014 & 2015 \\
\hline$T_{\text {, }}$ & $65.29 \mathrm{j}$ & $62.58 \mathrm{i}$ & $10.96 \mathrm{f}$ & $10.51 \mathrm{~h}$ \\
\hline$T_{2}$ & $67.70 \mathrm{i}$ & $73.30 \mathrm{~d}$ & $11.35 \mathrm{e}$ & $12.33 \mathrm{c}$ \\
\hline$T_{3}$ & $69.62 \mathrm{~h}$ & $64.21 \mathrm{~h}$ & $11.96 \mathrm{de}$ & $10.79 \mathrm{~g}$ \\
\hline$T_{4}$ & $72.45 f$ & $62.78 \mathrm{i}$ & $12.61 \mathrm{bc}$ & $10.99 \mathrm{f}$ \\
\hline $\mathrm{T}$ & $71.88 \mathrm{~g}$ & $76.09 \mathrm{~b}$ & $12.07 \mathrm{~cd}$ & $12.78 \mathrm{~b}$ \\
\hline$T_{0}$ & $72.28 \mathrm{f}$ & $73.20 \mathrm{~d}$ & $12.14 \mathrm{~cd}$ & $12.29 \mathrm{c}$ \\
\hline $\mathrm{T}$ & $75.11 \mathrm{e}$ & $65.46 \mathrm{~g}$ & $12.17 \mathrm{bc}$ & $10.54 \mathrm{~h}$ \\
\hline $\mathrm{T}_{8}$ & $76.50 \mathrm{~d}$ & $71.53 \mathrm{e}$ & $12.85 \mathrm{~b}$ & $12.02 \mathrm{~d}$ \\
\hline$T_{9}$ & $80.37 \mathrm{c}$ & $67.71 \mathrm{f}$ & $13.50 \mathrm{bc}$ & $11.37 \mathrm{e}$ \\
\hline$T_{10}$ & $81.67 \mathrm{~b}$ & $75.60 \mathrm{c}$ & $13.72 \mathrm{a}$ & $12.72 \mathrm{~b}$ \\
\hline$T_{1}$ & $82.82 \mathrm{a}$ & $78.20 \mathrm{a}$ & $13.91 \mathrm{a}$ & $13.13 \mathrm{a}$ \\
\hline
\end{tabular}

Any values on the same vertical line for the same character having the same letter are not statistically different according to DMRT.

$\mathrm{T}_{1}=$ Control (Untreated trees). $\mathrm{T}_{2}=$ Mycorrhizae fungi at $15 \mathrm{~g} /$ tree/ year.

$\mathrm{T}_{3}=\mathrm{T}_{2}+$ Sulphur at $1 \mathrm{~kg} /$ tree/ year. $\mathrm{T}_{4}=\mathrm{T}_{2}+$ Nile fertile at $750 \mathrm{~g} /$ tree/year.

$\mathrm{T}_{5}=\mathrm{T}_{2}+2 \mathrm{~cm} \mathrm{Bio-tol} / 1 \mathrm{~L}$ water was sprayed at Feb. up to May. $\mathrm{T}_{6}=\mathrm{T}_{2}+$ Sulphur $+30 \mathrm{ppm} \mathrm{GA}$ was sprayed at full bloom stage.

$\mathrm{T}_{7}=\mathrm{T}_{2}+$ Nile fertile +30 ppm GA3. $\mathrm{T}_{8}=\mathrm{T}_{2}+$ Bio-tol +30 ppm GA.

$\mathrm{T}_{9}=$ Phosphorine $\left(\right.$ Bio-fertal) at $11 \mathrm{~g} /$ tree/ year + Nile fertile. $\mathrm{T}_{10}=$ Phosphorine $($ Bio-fertal $)+$ Bio-tol +30 ppm GA . $\mathrm{T}_{11}=$ Phosphorine (Bio-fertal) + Sulphur +30 ppm GA $_{3}$.

\section{Fruit quality}

Physical fruit properties

Data in Table 5 show that there were significant differences among treatments in first season only as for fruit length and diameter, but the differences were not significant in the second one. Treated trees by $\mathrm{T}_{11}, \mathrm{~T}_{0}$ and $\mathrm{T}_{9}$ improved fruit dimention compared with the other treatments. The present results are in agreement with those found El-Mohamedy and Ahmed (2009) on mandarin trees, Vadak et al. (2014) on sweet oranges and El-Zawily (2016) on Washington Navel orange trees. They indicated that the trees inoculated with biofertilizers and Mycorrhizal fungi improved physical fruit quality in terms of fruit length and diameter in comparison to un-inoculated trees. Ahmed et al. (2013) on Valencia orange trees. They found that using sulpher as soil application was significantly very effective in improving fruit quality compared with the check treatment.

Also, Zaghloul (2004), Abo El-Enin (2005) on Washington navel oranges and Ismail (2007) on Tanarif sweet orange, reported that spraying $\mathrm{GA}_{3}$ increased fruit length and diameter compared with non-treated trees. Concerning peel thickness, data revealed that all treatments compared to control tended to increase peel thickness especially trees treated by $\mathrm{T}_{11}$. These results are in harmony with those obtained by Abd El-Migeed et al. (2007) and Reastegar and Rahemi (2008) on Washington J. Sus. Agric. Sci. Vol. 43, No.1 (2017)
Navel orange trees. Data also recorded a significant increase in juice weight percentage by $\mathrm{T}_{11}$ and $\mathrm{T}_{7}$ in the first season without significant differences between them while in the second one treated trees with $\mathrm{T}_{11}$ followed by $\mathrm{T}_{10}$ increased juice weight percentage compared with the other treatments and control. These results herein are in line with those obtained by Mohamed et al. (2009) on mandarin trees, and El-Zawily (2016) on Washington Navel orange trees. They showed that the usage of commercial bio fertilizers increased fruit juice weight percentage compared with control. However, Manju and Rawat (2015) on sweet orange trees, found that, spraying $\mathrm{GA}_{3}$ on trees increased juice weight percentage.

\section{Chemical fruit properties}

Data in Table 6 indicate that $\mathrm{T}_{11}$ gave fruits with higher SSC $\%$ followed by $\mathrm{T}_{10}, \mathrm{~T}_{9}, \mathrm{~T}_{8}$ and $\mathrm{T}_{7}$ compared to the lowest value resulted from $\mathrm{T}_{1}$ (control). The highest juice acidity $(\%)$ was resulted under $\mathrm{T}_{11}, \mathrm{~T}_{10}, \mathrm{~T}_{9}$, $\mathrm{T}_{8}, \mathrm{~T}_{7}$ and $\mathrm{T}_{6}$ without significant difference among them. Meanwhile, the control treatment $\left(\mathrm{T}_{1}\right)$ had significantly low value. Concerning of vitamin $\mathrm{C}$, data in the same table recorded that $\mathrm{T}_{11}$ and $\mathrm{T}_{10}$ gave the highest contents of vitamin $\mathrm{C}$ without significant differences between them in the first season while in the second one $T_{11}, T_{10}$ and $T_{7}$ gave the highest values followed by $T_{9}$ and $T_{8}$ without significant differences between them compared to control $\left(\mathrm{T}_{1}\right)$ in both seasons 
TABLE 5. Effect of some soil amendments and $\mathrm{GA}_{3}$ foliar application on physical quality of Washington Navel orange fruits in 2014 and 2015 seasons

\begin{tabular}{|c|c|c|c|c|}
\hline \multirow{2}{*}{ Characters } & \multicolumn{2}{|c|}{$\begin{array}{c}\text { Fruit length } \\
(\mathrm{cm})\end{array}$} & \multicolumn{2}{|c|}{$\begin{array}{c}\text { Fruit diameter } \\
(\mathrm{cm})\end{array}$} \\
\hline & 2014 & 2015 & 2014 & 2015 \\
\hline $\mathrm{T}$ & $7.44 \mathrm{f}$ & $8.72 \mathrm{a}$ & $7.37 \mathrm{~d}$ & $8.39 \mathrm{a}$ \\
\hline $\mathrm{T}$ & $7.71 \mathrm{de}$ & $9.25 \mathrm{a}$ & $7.48 \mathrm{~cd}$ & $8.65 \mathrm{a}$ \\
\hline & $7.83 \mathrm{~cd}$ & $8.98 \mathrm{a}$ & $7.58 \mathrm{bcd}$ & $8.64 \mathrm{a}$ \\
\hline & $7.96 \mathrm{bcd}$ & $8.58 \mathrm{a}$ & $7.95 \mathrm{abc}$ & $8.78 \mathrm{a}$ \\
\hline T & $7.55 \mathrm{ef}$ & $8.90 \mathrm{a}$ & $7.50 \mathrm{~cd}$ & $8.73 \mathrm{a}$ \\
\hline & $7.90 \mathrm{~cd}$ & $9.54 \mathrm{a}$ & $7.51 \mathrm{~cd}$ & $8.80 \mathrm{a}$ \\
\hline $\mathrm{T}$ & $7.87 \mathrm{~cd}$ & $8.67 \mathrm{a}$ & $7.36 \mathrm{~d}$ & $8.40 \mathrm{a}$ \\
\hline $\mathrm{T}_{\mathrm{s}}^{\prime}$ & $8.09 \mathrm{abc}$ & $8.87 \mathrm{a}$ & $8.00 \mathrm{ab}$ & $8.74 \mathrm{a}$ \\
\hline & $8.18 \mathrm{ab}$ & $8.63 \mathrm{a}$ & $8.07 \mathrm{a}$ & $8.59 \mathrm{a}$ \\
\hline & $8.25 \mathrm{a}$ & $9.21 \mathrm{a}$ & $8.17 \mathrm{a}$ & $8.87 \mathrm{a}$ \\
\hline$T_{11}^{10}$ & $8.32 \mathrm{a}$ & $8.72 \mathrm{a}$ & $8.35 \mathrm{a}$ & $8.73 \mathrm{a}$ \\
\hline
\end{tabular}

TABLE 5. Cont.

\begin{tabular}{|c|c|c|c|c|}
\hline \multirow{2}{*}{$\underbrace{\text { Characters }}_{\text {Treatmrents }}$} & \multicolumn{2}{|c|}{$\begin{array}{l}\text { Peel thickness } \\
\text { (cm) }\end{array}$} & \multicolumn{2}{|c|}{ Juice weight (\%) } \\
\hline & 2014 & 2015 & 2014 & 2015 \\
\hline $\mathrm{T}_{1}$ & $0.54 \mathrm{~b}$ & $0.29 \mathrm{~b}$ & $39.58 \mathrm{~g}$ & 24.67 \\
\hline $\mathrm{T}$ & $0.59 \mathrm{ab}$ & $0.35 \mathrm{ab}$ & $39.39 \mathrm{~g}$ & $16.61 \mathrm{~h}$ \\
\hline & $0.59 \mathrm{ab}$ & $0.29 \mathrm{~b}$ & 44.21 d & $22.55 \mathrm{e}$ \\
\hline & $0.56 \mathrm{~b}$ & $0.36 \mathrm{ab}$ & $\frac{47.70 d}{4231}$ & $\frac{22.05 \mathrm{e}}{1944 \mathrm{~g}}$ \\
\hline & $0.60 \mathrm{ab}$ & $\frac{0.42 \mathrm{a}}{0.32 \mathrm{~b}}$ & $42.31 \mathrm{e}$ & $\frac{19.44 \mathrm{~g}}{21.98 \mathrm{f}}$ \\
\hline & $0.60 \mathrm{ab}$ & $0.32 \mathrm{~b}$ & $48.06 \mathrm{a}$ & $22.09 \mathrm{e}$ \\
\hline $\mathrm{T}_{8}^{7}$ & $0.61 \mathrm{ab}$ & $0.34 \mathrm{ab}$ & $41.79 \mathrm{f}$ & $15.94 \mathrm{i}$ \\
\hline$T_{9}^{8}$ & $0.64 \mathrm{a}$ & $0,32 \mathrm{~b}$ & $47.93 \mathrm{c}$ & $23.80 \mathrm{~d}$ \\
\hline$T^{10}$ & $\frac{0.65 a}{0.66 a}$ & $\frac{0.35 \mathrm{ab}}{0.42 \mathrm{a}}$ & $\begin{array}{l}47.85 \mathrm{~b} \\
48.62 \mathrm{a}\end{array}$ & $\frac{25.80 \mathrm{~b}}{28.78 \mathrm{a}}$ \\
\hline
\end{tabular}

Any values on the same vertical line for the same character having the same letter are not statistically different according to DMRT.

$\mathrm{T}_{1}=$ Control (Untreated trees). $\mathrm{T}_{2}=$ Mycorrhizae fungi at $15 \mathrm{~g} /$ tree/ year.

$\mathrm{T}_{3}=\mathrm{T}_{2}+$ Sulphur at $1 \mathrm{~kg} /$ tree/ year. $\mathrm{T}_{4}=\mathrm{T}_{2}+$ Nile fertile at $750 \mathrm{~g} /$ tree/year.

$\mathrm{T}_{5}=\mathrm{T}_{2}+2 \mathrm{~cm}$ Bio-tol /IL water was sprayed at Feb. up to May. $\mathrm{T}_{6}=\mathrm{T}_{2}+$ Sulphur +30 ppm GA 3 was sprayed at full bloom stage.

$\mathrm{T}_{7}=\mathrm{T}_{2}+$ Nile fertile +30 ppm GA3. $\mathrm{T}_{8}=\mathrm{T}_{2}+$ Bio-tol +30 ppm GA.

$\mathrm{T}_{9}=$ Phosphorine (Bio-fertal) at $11 \mathrm{~g} /$ tree/ year + Nile fertile. $\mathrm{T}_{10}=$ Phosphorine $($ Bio-fertal $)+$ Bio-tol +30 ppm GA .

$\mathrm{T}_{11}=$ Phosphorine $($ Bio-fertal $)+$ Sulphur +30 ppm GA .

TABLE 6. Effect of some soil amendments and $\mathrm{GA}_{3}$ foliar application on chemical quality of Washington navel orange fruits in 2014 and 2015 seasons

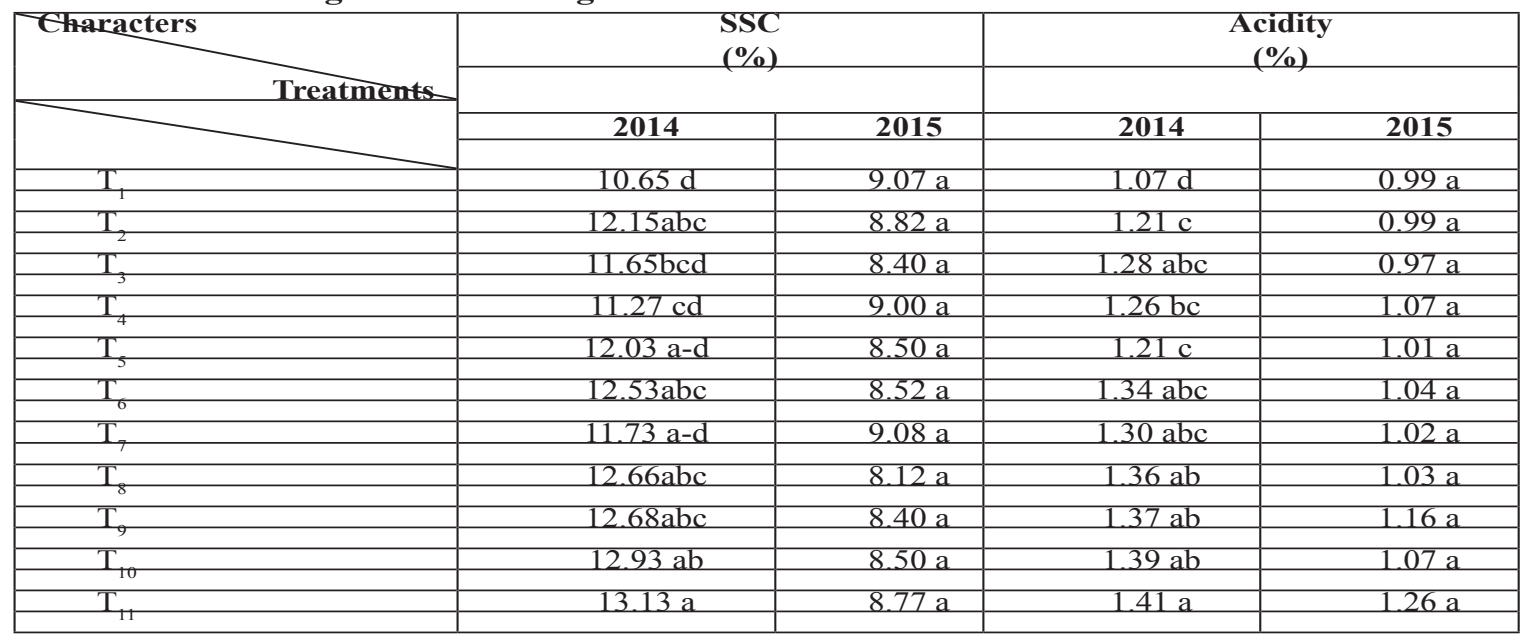


TABLE 6. Cont.

\begin{tabular}{|c|c|c|c|c|}
\hline \multirow{2}{*}{$\begin{array}{l}\text { Characters } \\
\text { Treatments }\end{array}$} & \multicolumn{2}{|c|}{ SSC/Acid ratio } & \multicolumn{2}{|c|}{$\begin{array}{c}\text { Vitamin } \mathrm{C} \\
\text { (mg ascorbic acid } / 100 \mathrm{ml} \text { fresh juice) }\end{array}$} \\
\hline & 2014 & 2015 & 2014 & 2015 \\
\hline $\mathrm{T}$ & $9.97 \mathrm{a}$ & $9.36 \mathrm{a}$ & $36.72 \mathrm{~d}$ & $35.81 \mathrm{~d}$ \\
\hline $\mathrm{T}_{2}$ & $10.04 \mathrm{a}$ & $9.03 \mathrm{a}$ & $40.23 \mathrm{c}$ & $40.96 \mathrm{bc}$ \\
\hline$T_{3}$ & $9.25 \mathrm{a}$ & $9.17 \mathrm{a}$ & $42.48 \mathrm{bc}$ & $37.37 \mathrm{~cd}$ \\
\hline$T_{4}$ & $8.97 \mathrm{a}$ & $8.59 \mathrm{a}$ & $42.65 \mathrm{bc}$ & $41.52 \mathrm{bc}$ \\
\hline$T_{3}$ & $10.03 \mathrm{a}$ & $8.47 \mathrm{a}$ & $41.97 \mathrm{c}$ & $38.50 \mathrm{~cd}$ \\
\hline$T_{6}$ & $9.41 \mathrm{a}$ & $8.43 \mathrm{a}$ & $41.37 \mathrm{c}$ & $44.30 \mathrm{ab}$ \\
\hline$T_{7}$ & $8.96 \mathrm{a}$ & $9.31 \mathrm{a}$ & $43.67 \mathrm{abc}$ & $46.65 \mathrm{a}$ \\
\hline $\mathrm{T}_{8}$ & $9.30 \mathrm{a}$ & $7.18 \mathrm{a}$ & $41.92 \mathrm{c}$ & $43.60 \mathrm{ab}$ \\
\hline $\mathrm{T}_{\mathrm{g}}$ & $9.23 \mathrm{a}$ & $7.41 \mathrm{a}$ & $42.30 \mathrm{c}$ & $45.51 \mathrm{ab}$ \\
\hline$T_{+\infty}$ & $9.30 \mathrm{a}$ & $8.09 \mathrm{a}$ & $45.72 \mathrm{ab}$ & $47.79 \mathrm{a}$ \\
\hline$T_{\text {t }}$ & $9.31 \mathrm{a}$ & $7.05 \mathrm{a}$ & $46.57 \mathrm{a}$ & $47.65 \mathrm{a}$ \\
\hline
\end{tabular}

Any values on the same vertical line for the same character having the same letter are not statistically differen according to DMRT.

$\mathrm{T}_{1}=$ Control (Untreated trees). $\mathrm{T}_{2}=$ Mycorrhizae fungi at $15 \mathrm{~g} /$ tree $/$ year.

$\mathrm{T}_{3}=\mathrm{T}_{2}+$ Sulphur at $1 \mathrm{~kg} /$ tree/ year. $\mathrm{T}_{4}=\mathrm{T}_{2}+$ Nile fertile at $750 \mathrm{~g} /$ tree/year.

$\mathrm{T}_{5}=\mathrm{T}_{2}+2 \mathrm{~cm}$ Bio-tol $/ 1 \mathrm{~L}$ water was sprayed at Feb. up to May. $\mathrm{T}_{6}=\mathrm{T}_{2}+$ Sulphur $+30 \mathrm{ppm} \mathrm{GA}$ was sprayed at full bloom stage.

$\mathrm{T}_{7}=\mathrm{T}_{2}+$ Nile fertile +30 ppm GA3. $\mathrm{T}_{8}=\mathrm{T}_{2}+$ Bio-tol +30 ppm GA.

$\mathrm{T}_{9}=$ Phosphorine $\left(\right.$ Bio-fertal) at $11 \mathrm{~g} /$ tree/ year + Nile fertile. $\mathrm{T}_{10}=$ Phosphorine $($ Bio-fertal $)+$ Bio-tol $+30 \mathrm{ppm}$ $\mathrm{GA}_{3}$.

$\mathrm{T}_{11}=$ Phosphorine (Bio-fertal) + Sulphur +30 ppm GA .

The above mentioned results are in accordance with those reported by El-khawega and Maklad (2013) on Valencia orange trees, El- khayat and Abd El-Rehiem (2013) on Balady mandarin trees, Dutta et al. (2014), Vadak et al. (2014) on Sweet oranges and El-Zawily (2016) on Washington Navel orange trees. They found that treated trees with bio-fertilizers and Mycorrhizal fungi increased TSS, total acidity $\%$, SSC / acid ratio and vitamin $\mathrm{C}$ content compared with non- treated trees. While, Ashour et al. (2009) on Balady orange trees and Ahmed et al. (2013) on Valencia orange trees. They showed that $\mathrm{SSC} \%$, SSC/acid ratio, vitamin $\mathrm{C}$ content were increased while total acidity $\%$ was decreased when the trees treated with Nile fertile + citric acid + Dynamic compared with untreated trees. However, Ibrahim (2007) on Valencia orange trees and Saleem et al. (2008) on Balady sweet orange trees, they showed that, spraying the trees with $\mathrm{GA}_{3}$ improved chemical fruit quality (SSC, vitamin $\mathrm{C}$ and acidity) compared to unsprayed trees.

\section{Soil properties}

Soil $p H$ and salinity (EC)

Data obtained in Table 7 show that values of soil $\mathrm{pH}$ were slightly decreased with applying $\mathrm{T}_{11}, \mathrm{~T}_{10}, \mathrm{~T}_{9}$, $\mathrm{T}_{8}, \mathrm{~T}_{7}, \mathrm{~T}_{6}$ and $\mathrm{T}_{5}$ comparing with other treatments and control $\left(\mathrm{T}_{1}\right)$. Moreover, EC values were decreased J. Sus. Agric. Sci. Vol. 43, No.1 (2017)

with all soil amendments treatments compared with control. These results are in harmony with those obtained by Miller et al. (1990) showed that the beneficial effects of sulphur on fruiting of Valencia orange trees might be attributed to its favorable effects on decreasing soil $\mathrm{pH}$ and soil salinity as well as increasing uptake of all nutrients. Also, Idso et al. (1995), Zeerban et al (2000), Atom (2013), and Soliman and Aaid (2016) found that soil $\mathrm{pH}$ and EC slightly decreased with applied sulphur and biofertilizers as soil application compared with control. Available soil macronutrients and its organic matter

Data presented in Table 7 show that the soil available macronutrients ( $\mathrm{N}, \mathrm{P}$ and $\mathrm{K}$ ) and organic matter $\%$ tended to increase with all soil amendments treatments compared to untreated trees. These results in confirmed with those obtained by Zeerban et al (2000), Miretal.(2014), SolimanandAaid(2016) and Zayan et al. (2016). They found that soil amendment treatments including sulfur and bio-fertilizers significantly increased available soil $\mathrm{N}, \mathrm{P}, \mathrm{k}$ and soil organic matter content compared with control. 
TABLE 7. Effect of some soil amendments and $\mathrm{GA}_{3}$ foliar application on some physical and chemical properties at the end of experiment

\begin{tabular}{|c|c|c|c|c|c|c|}
\hline \multirow{2}{*}{ Characters } & \multirow[b]{2}{*}{$\mathbf{p H}$} & \multirow{2}{*}{ 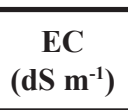 } & \multicolumn{3}{|c|}{ Available macronutrients (ppm) } & \multirow{2}{*}{$\begin{array}{c}\text { O.M. } \\
(\%)\end{array}$} \\
\hline & & & $\mathbf{N}$ & $\mathbf{P}$ & $\mathbf{K}$ & \\
\hline $\mathrm{T}_{1}$ & 8.30 & 2.43 & 25.65 & 7.02 & 372.90 & 1.07 \\
\hline $\mathrm{T}_{2}$ & 8.10 & 1.64 & 24.47 & 7.17 & 381.13 & 1.22 \\
\hline $\mathrm{T}_{3}$ & 8.00 & 1.62 & 23.50 & 7.13 & 382.83 & 1.24 \\
\hline $\mathrm{T}_{4}$ & 8.03 & 1.65 & 24.44 & 7.17 & 380.20 & 1.32 \\
\hline $\mathrm{T}_{5}$ & 7.92 & 1.59 & 25.43 & 7.17 & 381.13 & 1.29 \\
\hline $\mathrm{T}_{6}$ & 7.96 & 1.60 & 24.37 & 7.18 & 381.83 & 1.32 \\
\hline $\mathrm{T}_{7}$ & 7.93 & 1.57 & 25.40 & 5.16 & 381.33 & 1.32 \\
\hline $\mathrm{T}_{8}$ & 7.85 & 1.72 & 25.10 & 7.15 & 380.83 & 1.33 \\
\hline $\mathrm{T}_{9}$ & 7.93 & 1.70 & 25.80 & 7.21 & 381.83 & 1.26 \\
\hline $\mathrm{T}_{10}$ & 7.83 & 1.88 & 26.13 & 7.23 & 380.80 & 1.23 \\
\hline$T_{11}$ & 7.88 & 1.89 & 25.1 & 7.39 & 382.17 & 1.28 \\
\hline
\end{tabular}

Any values on the same vertical line for the same character having the same letter are not statistically different according to DMRT. $\mathrm{T}_{1}=$ Control (Untreated trees). $\mathrm{T}_{2}=$ Mycorrhizae fungi at $15 \mathrm{~g} /$ tree $/$ year.

$\mathrm{T}_{3}=\mathrm{T}_{2}+$ Sulphur at $1 \mathrm{~kg} /$ tree/ year. $\mathrm{T}_{4}=\mathrm{T}_{2}+$ Nile fertile at $750 \mathrm{~g} /$ tree/year.

$\mathrm{T}_{5}=\mathrm{T}_{2}+2 \mathrm{~cm}$ Bio-tol / IL water was sprayed at Feb. up to May.

$\mathrm{T}_{6}=\mathrm{T}_{2}+$ Sulphur +30 ppm GA 3 was sprayed at full bloom stage.

$\mathrm{T}_{7}=\mathrm{T}_{2}+$ Nile fertile +30 ppm GA3. $\mathrm{T}_{8}=\mathrm{T}_{2}+$ Bio-tol +30 ppm GA .

$\mathrm{T}_{9}=$ Phosphorine (Bio-fertal) at $11 \mathrm{~g} /$ tree/ year + Nile fertile. $\mathrm{T}_{10}=$ Phosphorine (Bio-fertal) + Bio-tol $+30 \mathrm{ppm} \mathrm{GA}$.

$\mathrm{T}_{11}=$ Phosphorine (Bio-fertal) + Sulphur +30 ppm GA .

Soil microbial counts and dehydrogenase activity

Data in Figs. 1 and 2 illustrate that there were significant differences among all treatments. Microbial counts (colonies number of fungi, bacteria and yeast) and dehydrogenase activity were increased under $T_{7}$ and $T_{8}$ followed in decreasing order $\mathrm{T}_{10}, \mathrm{~T}_{11}, \mathrm{~T}_{3}, \mathrm{~T}_{4}, \mathrm{~T}_{9}$ and $\mathrm{T}_{6}$ in both seasons. This increasing may due to the essential roles of organic and bio-fertilization on enhancing soil fertility, micro-flora activity, natural hormones, antioxidants, vitamins $\mathrm{B}$ and antibiotics which resulted in enhancing dehydrogenase activity (Dahama, 1999 and Kannaiyan, 2002). The obtained results are in agreement with those reported by Rizk-Alla and Tolba(2010),Allametal.(2012), Mir etal.(2014)and Zayan et al. (2016). They reported that application of bio-fertilizers, arbuscular mycorrhizae (AM) fungi and Nile fertile gave the highest soil microorganisms (fungi, bacteria and yeast) content and the dehydrogenase activity compared with control.

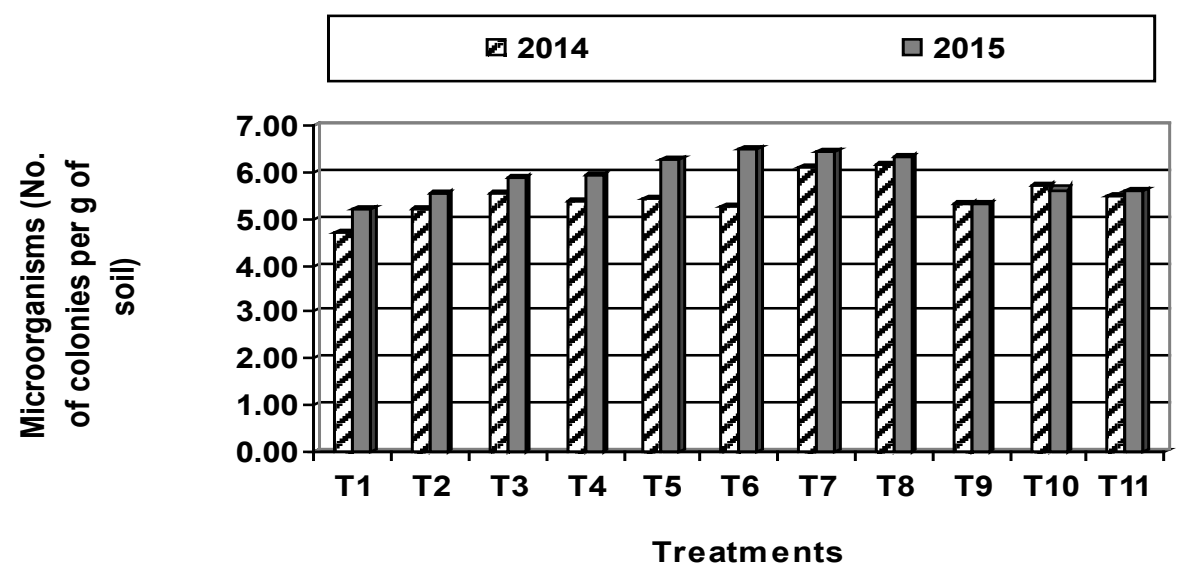

Fig. 1. Effect of some soil amendments and $\mathrm{GA}_{3}$ foliar application on soil microbial counts in 2014 and 2015 seasons 


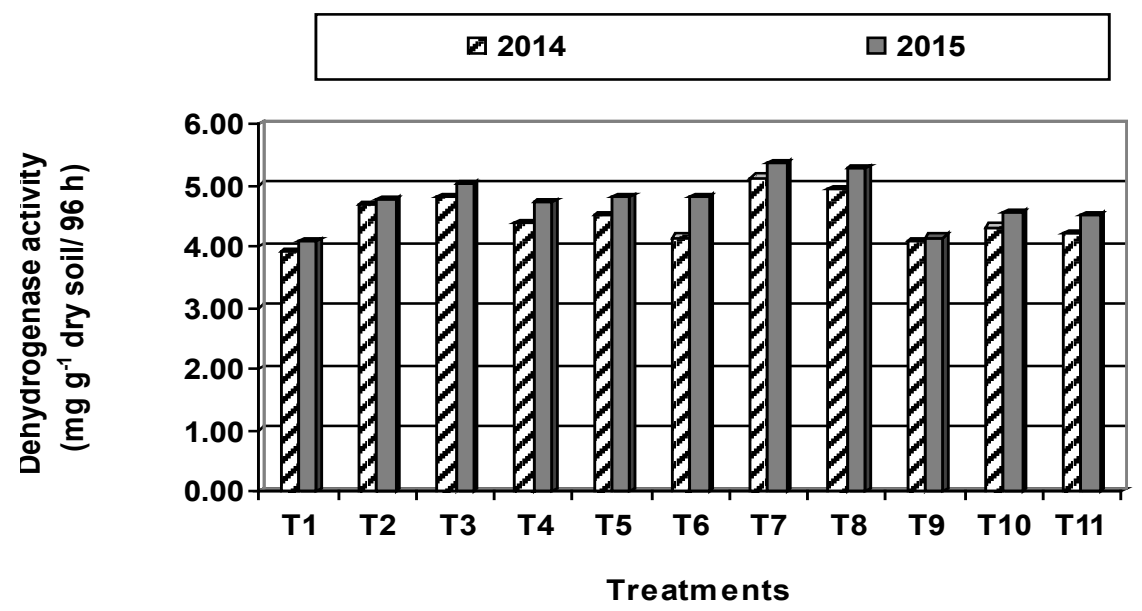

Fig. 2. Effect of some soil amendments and $\mathrm{GA}_{3}$ foliar application on soil dehydrogenase activity in 2014 and 2015 seasons

\section{Conclusion}

From the obtained results, it could be recommended Washington Navel orange growers on clay soil to add $\mathrm{T}_{11}$ or $\mathrm{T}_{10}$ followed by $\mathrm{T}_{9}$ and $\mathrm{T}_{7}$ treatments for its positive effects on most soil properties and stimulating vegetative growth and improving nutritional status, yield and fruit quality of Washington Navel orange trees under conditions of this experiment at Kafrelsheikh governorate.

\section{References}

A.O.A.C. (1990) Association of Official Analytical Chemists. "Official Methods of Analysis". 15 $5^{\text {th }}$ ed., Washington D.C., USA.

Abd El-Raheem, M.E., Abd El-Rahman, G.F., Mohamed, H.M. and Elharony, S.B. (2013) Regulation of Navel orange cropping and improvement of fruit quality using sitofex and gibberellic acid. Nature and Science, 11 (6), 13-21.

Abd El-Migeed, M.M.M, Saleh, M.M.S. and Mostafa, E.A.M. (2007) The beneficial effect of minimizing mineral nitrogen fertilization on washing navel orange trees by using organic and bio fertilizers. World J. Agric. Sci., 3 (1), 80-85.

Abdel-Nasser, G. and El-Shazly, S.M. (2000) Effect of sulphur application on soil properties, nutrient status, yield and fruit quality of Balady orange trees. J. Agric. Res., Tanta Univ., 26, 72-92.

Abo El-Enin, M.M.S. (2005) Studies on fruit abscission zone of Valencia and navel orange varieties. M.Sc. Thesis, Fac. Agric., Tanta Univ., Egypt.

Abo El-Enin, M.M.S. (2012) Improvement of Washington Navel orange fruit quality using water regimes and $\mathrm{GA}_{3}$, potassium and calcium foliar applications. Ph.D. Thesis, Fac. Agric., Kafrel-Sheikh Univ., Egypt.

J. Sus. Agric. Sci. Vol. 43, No.1 (2017)
Abou-Zeed, E.A.A, El-Salhy, A.M., Abdel-Galil, H.A. and Badawy, F.M. (2014) Effect of yeast and different phosphorus fertilizer sources on growth and fruiting of Balady mandarin trees. Assiut $J$. Agric. Sci., 45 (3), 49-64.

Ahmed H.M, Abdelaal, F. F., EL-Masry, E.M.A. and Abdallah, A.A. (2013) Using potassium sulphur as well as organic and bio fertilization for Alleviating the adverse effects of salinity on growth and fruiting of Valencia orange trees. Stem Cell, 4 (4), 27-32.

Allam, A.M.A, Ahmed F.F., El-Hefnawy N.N., ElHewety M.A. and Khafagy H.A. (2012) Impact of inorganic $\mathrm{N}$ and compost enriched with some bacterial strains on fruiting of Superior and Flame seedless grapevines as well as activity of dehydrogenase enzyme in the soil. Minia $J$. of Agric. Res. \& Develop., 32 (3), 495-510.

Ashour, N.E., Hegab, M.M.Y. and Hegab, M.Y. (2009) Effect of some cultural practices to reducing the adverse effects of salinity on growth and fruiting of Balady orange trees. Journal Green Farming 2(11), 738-741.

Atom, A. (2013) Effect of inorganic and biofertilizers on growth, yield and quality of Sardar Guava (Psidium guajava L.). M.Sc.Thesis, College of Agriculture, Latur.

Castle, W. (1983) Growth, yield and cold hardiness of seven year old 'Bearss' lemon on twenty seven rootstocks. Proc. Florida Sta. Hort. Soc., 96, 23-25.

Chapman, H.D. and Pratt, P.F. (1978) Methods of analysis for soils, plant and water. Univ. California, USA.

Chien, S.H., Gearhart, M.M.and Villagarcía, S. (2011) Comparison of ammonium sulfate with other 
nitrogen and sulfur fertilizers in increasing crop production and minimizing environmental impact: a review. Soil Science, 176 (7), 327-335.

Chou, G.J. (1966) A new method of measuring the leaf area of citrus trees. Acta. Hort. Sin., 5, 17-20.

Dahama, A.K. (1999) Organic farming for sustainable agriculture. Agro Botanic, Daryagun, New Delhi, India, $258 \mathrm{p}$.

Duncan, D.B. (1955) Multiple range and multiple "F" test biometrics, 11:1-24.

Dutta. P., Kundu, S., Bauri, F.K., Talang, H. and Majumder, D. (2014) Effect of bio-fertilizer on physic-chemical qualities and leaf mineral composition of guava grown in alluvial zone of west Bengal. Journal of Crop and Weed, 10 (2), 268-271.

El-Deeb, M., Sourour, M.M., Nakhlla, F.G., ELAlakmy, H.A. and Fouad, M.A. (2013) Response of Valencia orange trees to some bio-fertilization treatments. Annals of Agric, Sci, Moshtohor, 51 (4), $371-382$.

El-Khawaga, A.S. (2007) Selecting the optimum amount of organic, mineral and bio-fertilizers responsible for maximizing the productivity of Balady guava. Egypt. J. Appl. Sci., 22 (5B).

El-Khawaga, A.S and Maklad, M.F. (2013) Effect of combination between bio and chemical fertilization on vegetative growth, yield and quality of Valencia orange fruits. Hortscience Journal of Suez Canal University, 1, 269-279.

El-Khayat, H.M. and Abdel Rehiem, M. A. (2013) Improving mandarin productivity and quality by using mineral and bio-fertilization. Alex. J. Agric. Res., 58(2), 141-147.

El-Mohamedy, R.S.R. and Ahmed, M.A. (2009) Effect of bio-fertilizers and humic acid on control of dry root rot disease and improvement yield quality of mandarin (Citrus reticulate Blanco). Res. J. Agric. \& Biol. Sci., 5(2), 127-137.

El-Zawily, H.M.A (2016) Evaluation the effect of different kinds of fertilizers on soil properties, vegetative growth, yield and fruit quality of "Washington navel" orange trees under different irrigation levels in sandy soil. Ph. D. Thesis, Fac. Agric., Kafr el-Sheikh Univ., Egypt.

Ferre, D.C. and C.G. Forshey (1988) Influence of pruning and urea spray on growth and fruiting of square bound Delicious apple trees. J. Amer. Soc. Hort. Sci., 113(5), 699-703.
Ibrahim, A.N. and Abd El-Aziz, I.M. (1977) Solubilization of rock phosphate by streptomyces. Agr. Talajton. 26, 424-434.

Ibrahim, H.M.F (2007) Effect of rootstock, pre- and postharvest treatments on fruit quality and storability of Valencia orange. M.Sc. Thesis, Fac. Agric. Kafr ElSheikh Univ., Egypt.

Idso, S.B., Idso, K.E., Garica, R.1., Kimball, B.A. and Hoober, J.k. (1995) Effects of atmospheric $\mathrm{CO}_{2}$ enrichment and foliar methanol application on net photosynthesis of sour orange tree (Citrus aurantium) leaves. American Journal of Botany 82(1), 26-30.

Ismail, M.N.H. (2007). Physiological studies on creasing of sweet orange. Ph.D. Thesis, Fac. Agric. Benha Univ.

Jackson, M.L. (1967) Soil chemical and analysis. Prentice Hall of India, New Delhi.

Kannaiyan, S. (2002). Biotechnology of Bio-fertilizers. Alpha Science Inter. Ltd., P.O. Box 4067 Pang Bourne, p.64.

Koller, O.C., Schafer, G.., Sartor, I.A.., Sohwarz, S.F. and Lima, J.G. (2000) Production of Navel orange cv. Mannte parnaso with branch girdling and application of plant growth regulators. Revista. Bras, Leira de Fruticultura, 22 (special tssue), 68-72.

Koriem, M.A. (1994) Effect of different rates and motheds of sulphur application on some soil properties and elemental leaf compostion of Succari orange. J. Agric. Res., Tanta Univ., 20 (2), 345-360.

Lindemann, W.C., Aburtto, J.J., Haffner, W.M. and Bono, A.A. (1991) Effect of sulfur source on sulfur oxidation. Soil Sci. Soc. Am. J., 55, 85-90.

Lindermann, R.G. (1988). Mycorrhizal interaction with the rhizosphere microflora: the mycorrhizosphere effect. Phytopathology, 78, 366- 371.

Manju and S.S. Rawat, (2015) Effect of bioregulators on fruit growth and development of local Malta (Citrus sinensis Osbeck) under valley conditions of Garhwal Himalaya. International Journal of Plant, Animal and Environmental Sciences, 5 (2), 105-108. Available online at www.ijpaes.com

Marks, G.C. and Kozlowski, T.T. (1973) Ecotmycorrhiza, their ecology and physiology. Academic press, New York.

Merwad, M.M.M., El-Shamma, S., Mansour, A.E.M. and Helal, M.E.M. (2014) The effect of nitrogen fertilizer and mycorrhizal fungi on productivity of citrus trees grown in Newly Reclaimed soil. Middle East Journal of Agriculture Research, 3 (3), 653-662. J. Sus. Agric. Sci. Vol. 43, No.1 (2017) 
Mikhael, G.B., Asaad, S.A. and Mohamed, S.A. (2009) Effect of soil inoculation mycorrhiza and application with sulphur on vegetative growth and nutritional status of young persimmon trees grown in calcareous soil. Annals of Agric. Sci., Moshtohor, 47(2), 233-244.

Miller, E.W., Donahue, R.L. and Miller, J.U. (1990) Soils: An introduction to soils and plant growth. 5th End. Prentice Hall International Inc., Englewood Cliffs, NJ. USA. pp: 303-339.

Ministry of Agriculture and Land Reclamation (2014) Bulletin of the agricultural statistics, part (2) Summer \& Nile crops, 2012/2013, Cairo, Egypt.

Mir, M., Hassan, G.I., Mir, A., Hassan A. and Sulaimani, M. (2014) Effects of bio-organics and chemical fertilizers on nutrient availability and biological properties of pomegranate orchard soil. Int. J. Fruits and Vegetables, 1(2), 24-27.

Mohamed, A.K., Ahmed, M.M. and EL-Akkad, A.K.A. (2009). Is it possible to the annual fertilization in mandarin orchard by using the bio-fertilizers? Assiut J. of Agric. Sci., 40(4): 37-68.

Mohamed, A.S.B. (2005) Survey of defects of orange in Egypt that limit their acceptability for exportation and ways and means for improvement. M.Sc. Thesis, Fac. Agric. Tanta Univ., Egypt.

Moran, R. (1982) Formula for determination of chlorophyllous pigments extracted with $\mathrm{N}$, N-dimethyl formamide. Plant Physiol., 69, 1376-1381.

Murovhi, N.R. (2013) Effect of different rates of sulphur fertilization on fruit yield and leaf mineral composition of 'Valencia' oranges in the subtropical environment of South Africa. Acta Horticulturae, 2(12), 303-310.

Murphy, J. and Riely, J.D. (1962) A modified single solution method for the determination of phosphate in natural water. Anal. Chem. Acta, 27, 31-36.

Navarro, M.J., Tornero, O.P. and Morte, A. (2014) Alleviation of salt stress in citrus seedling inoculated with arbuscular mycorrhizal fungi depends on the rootstock salt tolerance. Journal of Plant Physiology, 171, 76-85.

Nawar, A.M., El-Shamy, H.A. and Fawas, K. (1988) Growth leaf chlorophyll and carbohydrate metabolism of mycorrhizal sour orange seedlings. J. Agric. Res., Tanta Univ., 14 (2/11), 1064-1073.

Neilsen, D., E.J. Hogue., P.B. Hoyt., B.G. Drought (1993) Oxidation of elemental sulfur and acidification of calcareous orchard soils in southern British Columbia. Can. J. Soil Sci., 73:103-114.

J. Sus. Agric. Sci. Vol. 43, No.1 (2017)
Page, A.L., Miller, R.H. and Keeney, D.R. (1982) "Methods of Soil Analysis" part 2: chemical and microbiological properties second edition. Agronomy 920 Am. Soc. Agron. Inc. Soil Sci. Soc. Am. Inc. Pub. Madison, Wisconsin, USA.

Pawar N.S., Bharad, S.G., Bhusari, R.B. and Ulemale, P.H. (2014) Effect of integrated nutrient management on growth, yield and quality of acid lime. Journal of Life Sciences, 11 (4a), 995-1000.

Reastegar, S and Rahemi, M. (2008) Evaluation of concentration and time of application of gibberellic acid and 2-4-D isopropyl ester on some fruit characteristics in Navel oranges and Clementine mandarin. J. of Sci and Techn. Agric. and Natural Resources, 42 (1), 197-207.

Rizk-Alla, M. S and Tolba, H.I. (2010) The role of some natural soil conditioner and AM fungi on growth, root, density and distribution, yield and quality of Black Monukka grapevines grown on calcareous soil. Journal of American science 6(12): 253-263 (http :/ www.american science .org ).

Saleem, B.A., Malik, A.U.., Pervez, M.A. and Khan, A.S. (2008) Spring application of growth regulators affects fruit quality of 'Blood Red' Sweet orange, Pak. $J$. Bot., 40,(3), 1013-1023.

Saleh, M.M.M. (2002) Biological control of some soil disease on Corn. M.Sc. Fac. Agric. Kafr El-sheikh. Tanta University, P. 27.

Schafer, G, Koller, O.C., Sartoriano, I.A. and Dornelles, A. L.C. (2000) Effect of irrigation, shoot ringing and growth regulators on fruit retention of "Monte parson" navel orange. Revista Brasilleria de Fruit., 22(1), 118-123.

Shaban, A.E.A. and Mohsen, A.T. (2009) Response of citrus rootstocks and transplants to bio-fertilizers. $J$. Hort. Sci. \& Ornamen. Plants, 1 (2), 39-48.

Shamshiri, M.H, Usha, K. and Bhupinder, S. (2012) Growth and nutrient uptake responses of kinnow to vesicular arbuscular mycorrhizae. International Scholarly Research Network Agronomy. 2012, Article ID 535846, p. 7.

Sherief, S.H.A. (1997) Consumption of chemical fertilizers in Egypt between exiting and targeted levels of application. J. Agric. Sci. Mansoura Univ., 22, 3151-3165.

Shinde, B.B, Ingle, H.V., Dhawelia, D.U., Hajare, A.R. and Dhobe, S.G. (2008) Effect of plant growth regulators on size, yield and quality of acid lime. $J$. Soil and Grops., 18 (1), 117-120. (CAB Abstract). 
Singh, S. and Kappor, K.U. (1999) Inoculation with phosphate solublization microorganisms and vesicular mycorrhizal fungus improves dry matter and nutrients uptake by wheat grown in sandy soil. Biol. Fertil. Soils, 218, 139-144.

Snedecor, G.W. and Cochran, W.G. (1990) Statistical methods. $7^{\text {th }}$ Ed. Iowa State Univ. Press. Ames., Iowa, USA, p. 593.

Soliman, M.A.M and Aaid, M.A. (2016) Effect of some soil amendments application on soil properties and vegetative growth of Le Cont pear seedlings in the North Nile Delta region. J. Aric. Res. Kafr ElSheikh Univ. J. Plant production, 42 (1), 143-157.

Subba-Rao, N.S. (1993) Bio-fertilizers in Agriculture and Forestry, Oxford and IBH. Publishing Co. Pvt. Ltd, New Delhi 136- 149. Int. J. Curr Microbial. App. Sci., 3 (4), 384-400.

Tabatabai, M.A. (1982) Soil enzymes, Dehydrogenases. In: Methods of Soil Analysis. Part 2. Chemical and Microbiolgical Properties, R.H. Miller and D.R. Keeney (Ed.), Agron. Monography, 9, ASA and SSSA, Madison, WI.

Vadak, Y., Patil, M.B., Diwan, K. Diwan, K., Govind, B., Kadam, A. Nilesh, D. and Rohit, U. (2014) Interaction effect of bio-fertilizers along with reducing level of chemical fertilizers on physicochemical characters of sweet orange (Citrus sinensis Osback). Asian Journal of Horticulture, 9 (1), 64-67.

Zaghloul, A.E. (2004) Improvement storage ability of Washington Navel orange fruits under Kafr ElSheikh Governorate conditions. Ph.D. Thesis, Fac. Agric., Tanta Univ., Egypt.

Zayan, M.A., Sayed, R.A., El-Shereif, A.R. and ElZawily, H.M.A. (2016) Irrigation and fertilization programs for "Washington Navel" orange trees in sandy soil under desert climatic conditions. 1Effect on soil properties, vegetative growth and yield. J. Agric. Res., Kafrelsheikh Univ., 42 (2), 244-267.

Zeerban, M.S., Aly, M.M., Salama, M.I. and Mankolah, M.M. (2000) Effect of mycorrhizae, sewage sludge and sulphur Application on vegetative growth of Valencia and Navel orange young trees. J. Agric. Res .Tanta Univ., 26 (4), 676-690.

(Received 10/2/2017, accepted $15 / 4 / 2017$ ) 
إستجابة أشجار البرتقال بسره لبعض مُحسنات التربة والرش بالجبريلين تحت ظروف الأر اضي الطينية النجار النية

منقى الاين إبراهيم سلامه" ، رمضان أبو سريع سيد*" ،على رمضان الثريف* و ماهر منقولة عبد الرحيم *قسم الفاكهة ـ كلية الزراعة - جامعة كفر الثيخ و** قاعم بحوث الموالح ـ معهد بحوث البساتين - مركز البحوث الزر اعية - القاهرة - مصر.

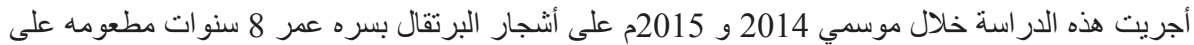

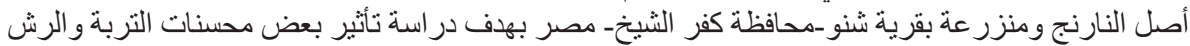

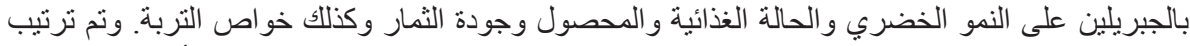

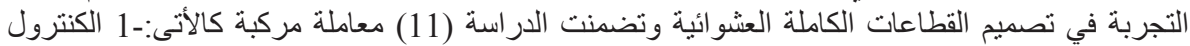

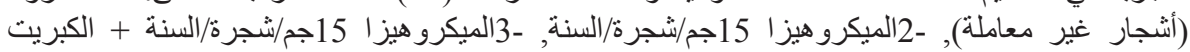

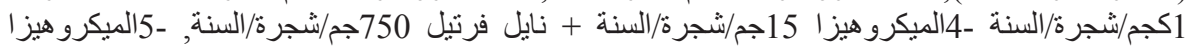

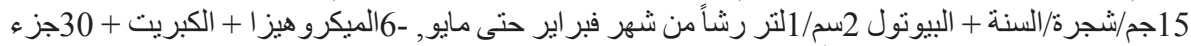

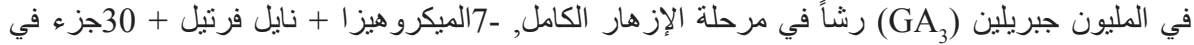

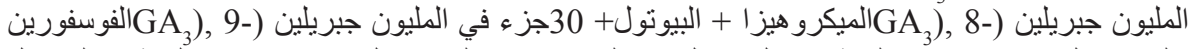

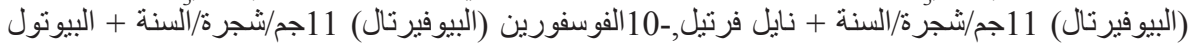

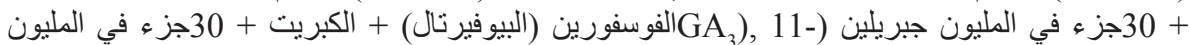

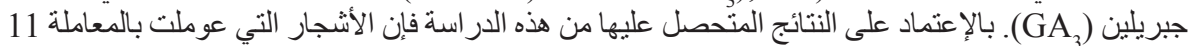

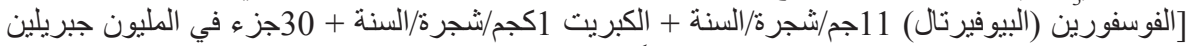

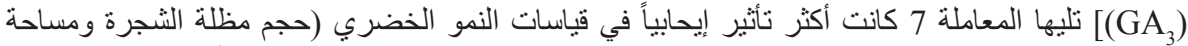

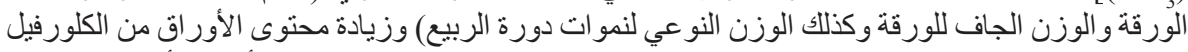

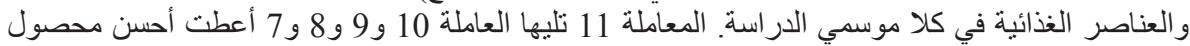

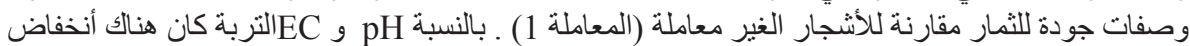

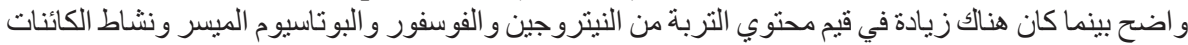
الحية الدقيقة وكذا نثاط انزيم الديهيدروجينيز للاشجار المعاملة بالمعاملات 11 و و10 و9 و7 مقارنة بالكنترول.

لذلك توصي هذه الدراسة مزارعي أثجار البرنقال بسره بإضافة المعاملة 11 أو المعاملة 7 أو إضافة

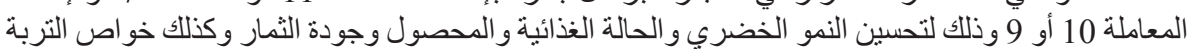
للحصول علي أعلى عائد لأشجار البرتقال بسره في الأرض الطينية تحت ظروف محافظة كفر الثيخ. 